\title{
In Vitro Response of Immunoregulatory Cytokine Expression in Human Monocytic Cells to Human Parvovirus B19 Capsid
}

\author{
Tetsuhiro Fusita, Hideaki Ikesima, Nanako Yamagata, Yuko Kudo, and Keiko Hoshi* \\ Department of Pharmacotherapeutics, Showa Pharmaceutical University; 3-3165 Higashitamagawagakuen, Machida, \\ Tokyo 194-8543, Japan. Received June 19, 2007; accepted August 30, 2007; published online September 3, 2007
}

\begin{abstract}
Human parvovirus B19 is a clinically important pathogen in both children and adults. In adults, it frequently causes acute and chronic arthritis, which may be related to persistent infection. The effect of the capsid of human parvovirus B19 on monocytes, which are thought to be responsible for the first line of defense against parvoviral infection, is not well understood. In this study, we investigated changes in mRNA expression levels of several immunoregulatory cytokines in monocytic cells after treatment with the B19 capsid. When human monocytic cell line THP-1 cells were treated with the B19 capsid, the expression of tumor necrosis factor alpha (TNF$\alpha$ ) mRNA was suppressed independently of transforming growth factor beta (TGF- $\beta$ ) mRNA. In contrast, the level of mRNA for interleukin-1 alpha (IL-1 $\alpha$ ) remained unchanged, and that for interleukin-1 beta (IL-1 $\beta$ ) was slightly increased after the capsid treatment. Flow cytometry demonstrated that THP-1 cells treated with B19 capsid showed no differences in surface expression of CD11a, CD16 and CD33, as compared with control cells. These findings that B19 capsid antigen did not promote positive responses for production of TNF- $\alpha$ and IL-1 $\alpha$ may provide insight into the mechanisms of persistent infection of human parvovirus B19 and the systemic viral spread via bloodstream.
\end{abstract}

Key words human parvovirus B19; VP1; VP2; monocyte; THP-1; persistent infection

Human parvovirus B19 (B19) was discovered in 1974 and is the only member of the family Parvoviridae that is known to be pathogenic for humans. ${ }^{1)}$ Nearly $50 \%$ of all people are positive for B19 antibody ${ }^{2)}$ and this virus is ubiquitous, but its manifestations vary with the immunologic and hematologic status of the host. In healthy immunocompetent children, B19 generally causes erythema infectiosum, an innocuous rash. Particularly in adults, B19 infection is occasionally associated with chronic symmetric polyarthropathy that may mimic rheumatoid arthritis, as well as with anemia and fetal hydrops, ${ }^{3-5)}$ which are caused by reactivation of persistent B19 infection. ${ }^{5)}$ The B19 virion has a simple structure composed of only two proteins (VP1 and VP2) and a linear, single-stranded DNA molecule. ${ }^{6)}$ The nonenveloped viral particles are about 22 to $24 \mathrm{~nm}$ in diameter and show icosahedral symmetry. After infection, two non-structural proteins (NS1 and NS2) are expressed by host cells. The effects of NS1 protein are well characterized, with the target cells of B19 being erythroid progenitor cells, liver cells, and monocyte/ macrophages, ${ }^{7,8)}$ and NS1 being expressed by these cells.

The B19 capsid is composed of two capsomer proteins (VP1 and VP2), which are encoded by overlapping reading frames. ${ }^{9,10)}$ VP2 is the major structural protein, accounting for $96 \%$ of all capsid protein. ${ }^{11)}$ This protein is encoded by the sequence from nt 3125 to 4786 and has a molecular mass of $58 \mathrm{kDa} .^{11,12)}$ The minor capsid protein, VP1, is encoded by the sequence from nt 2444 to 4786 and is identical to VP2 apart from the addition of 227 amino acids (termed the VP1unique region) at its amino terminus. ${ }^{11,12)} \mathrm{VP} 1$ protein has a molecular mass of $84 \mathrm{kDa}$ and makes up the remaining $4 \%$ of the capsid protein. ${ }^{11)}$

The monocyte is one of the important immunocompetent cells involved in fighting viral infection, which causes the differentiation of monocytes into macrophages. Macrophages have phagocytic activity and express important cytokines such as IL-1, IL-12, TNF- $\alpha$ and IFN- $\gamma$ after viral infection. Generally, unenveloped viruses are believed to insert pores into the plasma membrane or disrupt vesicle membranes within the endocytic pathway, but the mechanisms involved in the entry of naked viruses into monocytes are not fully understood.

B19 is difficult to culture in the laboratory. Bansal et al., empty capsids consisting of the two B19 structural proteins (VP1 and VP2) have already been used to mimic B19 infection in a murine model. ${ }^{13)}$

In the present study, we investigated the effect of B19 capsids on a human monocyte/macrophage cell line, including production of inflammatory cytokines and maturation.

\section{MATERIALS AND METHODS}

Cell Culture The human monocyte cell line THP-1 was maintained at $37^{\circ} \mathrm{C}$ under an atmosphere containing $5 \% \mathrm{CO}_{2}$ in RPMI-1640 medium supplemented with $1.5 \mathrm{~g} / 1$ sodium bicarbonate, $1 \mathrm{~mm}$ sodium pyruvate, $10 \mathrm{~mm}$ HEPES, $2.5 \mathrm{~g} / 1 \mathrm{D}-$ glucose, $0.05 \mathrm{~mm}$ 2-mercaptoethanol, and $10 \%$ fetal bovine serum. THP-1 cells were kindly donated by the Cell Resource Center for Biomedical Research, Institute of Development, Aging and Cancer, Tohoku University (Miyagi, Japan).

VP Antigen Recombinant empty capsid protein of human parvovirus B19 (rB19ECP) was kindly provided by Denka Seiken (Tokyo, Japan). rB19ECP was composed of VP1 and VP2 at a ratio of $5: 95$, respectively.

Treatment with LPS THP- 1 cells $\left(5 \times 10^{5}\right.$ cells per well) were dispensed into 6-well culture plates and incubated for $24 \mathrm{~h}$ at $37^{\circ} \mathrm{C}$ under $5 \% \mathrm{CO}_{2}$. The cells were then treated with lipopolysaccharide (LPS) ( $1 \mu \mathrm{g} / \mathrm{ml}$; Sigma, Tokyo, Japan) and incubated for 2 to $24 \mathrm{~h}$.

Treatment with VP Antigen THP- 1 cells $\left(5 \times 10^{5}\right.$ cells per well) were dispensed into 6-well culture plates and incubated for $24 \mathrm{~h}$ at $37^{\circ} \mathrm{C}$ under $5 \% \mathrm{CO}_{2}$. The cells were then treated with VP antigen $(0.1,0.5,1 \mu \mathrm{g} / \mathrm{ml})$ and incubated for 2 to $24 \mathrm{~h}$.

RNA Extraction and Reverse Transcription-Polymerase 
Chain Reaction (RT-PCR) Total RNA was extracted from cells using an RNeasy Mini Kit (Qiagen, Tokyo, Japan) according to the manufacturer's protocol for animal cells. The concentration of RNA was measured by spectrophotometry and the samples were stored at $-80^{\circ} \mathrm{C}$ until use. Reverse transcription of $1 \mu \mathrm{g}$ RNA was performed with Superscript III (Invitrogen, Tokyo, Japan). The resulting cDNA (1 $\mu \mathrm{l})$ was then subjected to PCR with specific primers for TNF- $\alpha$ (5'-gagtgacaagcetgtagcccatgttgtagca-3' and $5^{\prime}$-gcaatgatcccaaagtagacctgcccagact-3'), ${ }^{14)}$ IL-1 $\alpha \quad\left(5^{\prime}\right.$-ccactccatgaaggetgcatg- $3^{\prime}$ and $5^{\prime}$-ggtgctgacctaggettgatg- $\left.3^{\prime}\right),{ }^{15)}$ IL- $1 \beta\left(5^{\prime}\right.$-cctgtggccttgggcctcaa- $3^{\prime}$ and $5^{\prime}$-ggtgctgatgtaccagttggg- $\left.3^{\prime}\right),{ }^{15)}$ TGF$\beta\left(5^{\prime}\right.$-gccetggacaccaactattgct- $3^{\prime}$ and $5^{\prime}$-aggctccaaatgtaggggcagg- $\left.3^{\prime}\right){ }^{16)}$ and $\beta$-actin (5'-gacaggatgcagaaggagat- $3^{\prime}$ and $5^{\prime}$-ctagaagcatttgcggtgga- $\left.3^{\prime}\right) .{ }^{17}$ PCR was performed in a GoTaq (Promega, Tokyo, Japan) with primers and cDNAs in a Thermal Cycler Dice (TaKaRa, Tokyo, Japan). The conditions were $94^{\circ} \mathrm{C}$ for $5 \mathrm{~min}$ followed by 20,25 and 30 cycles of $94{ }^{\circ} \mathrm{C}$ for $30 \mathrm{~min}, 60^{\circ} \mathrm{C}$ for $30 \mathrm{~s}$, and $72{ }^{\circ} \mathrm{C}$ for $1 \mathrm{~min}$. PCR products were visualized by $1 \%$ agarose gel electrophoresis and staining with ethidium bromide. The levels of transcripts were normalized for host cell expression of $\beta$-actin mRNA.

Flow Cytometry THP-1 cells were cultured with or without VP antigen $(1 \mu \mathrm{g} / \mathrm{ml})$ and PMA $(5 \mathrm{ng} / \mathrm{ml})^{18)}$ for $24 \mathrm{~h}$ and then flow cytometry was performed as described previously. ${ }^{19)}$ Briefly, cells were washed with $0.2 \%$ BSA/PBS, followed by incubation for $20 \mathrm{~min}$ at $4{ }^{\circ} \mathrm{C}$ with monoclonal antibodies (anti-CD45, anti-CD11a, anti-CD16 and anti-CD33). Then lysing reagent was added to the cells and incubation was done for $10 \mathrm{~min}$. The cells were subsequently washed twice with PBS, followed by analysis on a FACSCalibur (Becton Dickinson, Tokyo, Japan) flow cytometer.

Statistical Analysis Statistical analysis was performed with Student's $t$-test and Dunnett's test, and $p<0.05$ was considered to indicate statistical significance.

\section{RESULTS}

Expression of TNF- $\alpha$ mRNA by LPS-Treated THP-1 Cells To confirm that THP- 1 cells could express TNF- $\alpha$ mRNA, these cells were treated with LPS. The level of TNF$\alpha$ mRNA showed a significant increase compared with that in control cells after 6 and $24 \mathrm{~h}$ of LPS treatment (Fig. 1), confirming that THP- 1 cells can express TNF- $\alpha$.

Expression of Cytokines by Capsid-Treated THP-1 Cells The growth of THP-1 cells treated with VP antigen showed no difference from the control (Fig. 2). We investigated the expression of mRNAs for inflammatory cytokines, such as TNF- $\alpha$, IL- $1 \alpha$, IL- $1 \beta$, and TGF- $\beta$, after THP- 1 cells were treated with VP antigen $(0.1,0.5$, or $1 \mu \mathrm{g} / \mathrm{ml})$. The level of TNF- $\alpha$ mRNA was suppressed compared with the control after $12 \mathrm{~h}(0.5,1 \mu \mathrm{g} / \mathrm{ml})$ of treatment (Fig. 3). We observed quite similar suppressive effects (approx. 30\% suppression) when the PCR was conducted in either 25 or 30 cycle (Figs. $3 \mathrm{~A}, \mathrm{~B}$ ), indicating the reproducible suppression of TNF- $\alpha$ mRNA upon the treatment with VP antigen. The levels of IL$1 \alpha$ mRNA in the VP-treated cells showed no significant change compared with those in control cells (Fig. 4), but IL$1 \beta$ mRNA was slightly increased after $6 \mathrm{~h}$ of treatment at $1 \mu \mathrm{g} / \mathrm{ml}$, as compared with the control (Fig. 5). The level of

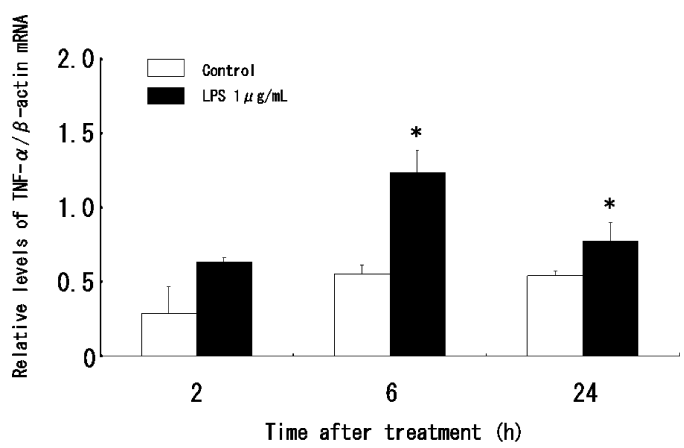

Fig. 1. TNF- $\alpha$ mRNA Expression by THP-1 Cells Treated with LPS

TNF- $\alpha$ mRNA expression was compared in the presence (closed columns) and absence (open columns) of LPS. Data represent the mean \pm S.D. $(n=3)$. Asterisks indicate a significant difference $(p<0.05)$ from untreated control cells.

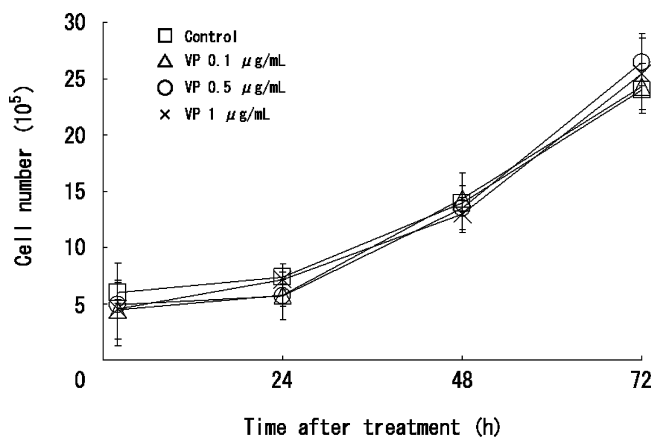

Fig. 2. Growth of THP-1 Cells with or without B19 Capsid Treatment

Values represent the mean \pm S.D. $(n=3)$. Significant difference $(* p<0.05)$ from the cell count for untreated control cells.

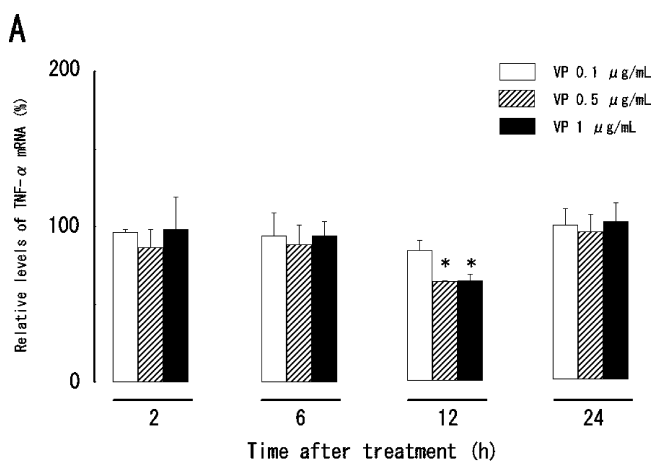

B

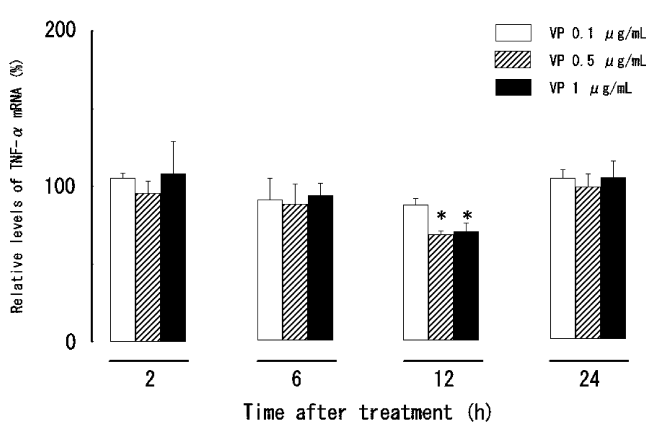

Fig. 3. TNF- $\alpha$ mRNA Expression by THP-1 Cells Treated with B19 Capsid

TNF- $\alpha$ mRNA levels were compared after incubation in the presence and absence of the empty capsid. TNF- $\alpha$ mRNA levels were normalized for the $\beta$-actin level using densitometry. Results are presented as the ratio (\%) of treated to untreated cells (mean \pm S.D., $n=3$ ). Significant differences from the values obtained with untreated control cells $(* p<0.05)$ were detected after $12 \mathrm{~h}$ of treatment at 0.5 and $1 \mu \mathrm{g} / \mathrm{ml}$. A and B show 25 and 30 cycles in PCR conditions respectively. 

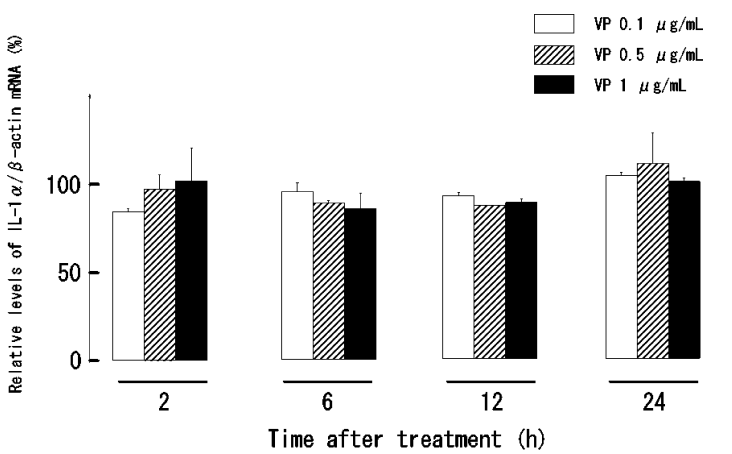

Fig. 4. IL- $1 \alpha$ mRNA Expression by THP-1 Cells Treated with B19 Capsid

IL- $1 \alpha$ expression was compared in the presence and absence of the empty capsid. IL- $1 \alpha$ mRNA levels were normalized for $\beta$-actin using densitometry. Results are presented as the ratio (\%) of treated cells to untreated control cells (mean \pm S.D., $n=3$ ). No significant differences were detected after B19 capsid treatment.

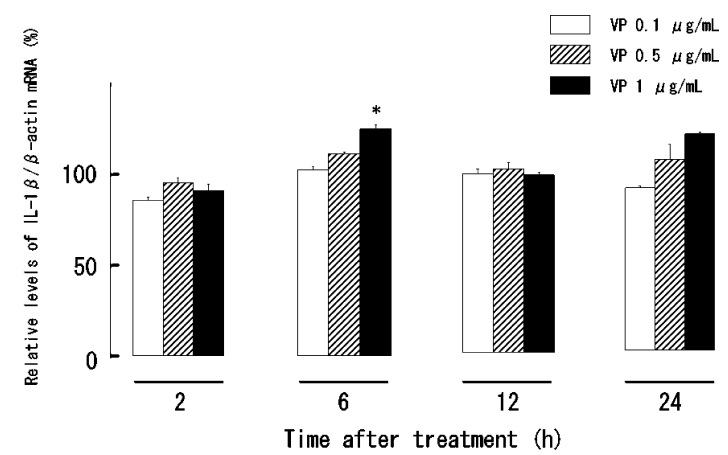

Fig. 5. IL-1 $\beta$ mRNA Expression by THP-1 Cells Treated with B19 Capsid

IL-1 $\beta$ expression was compared in the presence and absence of the empty capsid, and was normalized for that of $\beta$-actin using densitometry. Results are presented as the ratio $(\%)$ of treated cells to untreated cells (mean \pm S.D., $n=3$ ). Significant differences $(* p<0.05)$ from control cells were detected after $6 \mathrm{~h}$ of treatment at $1 \mu \mathrm{g} / \mathrm{ml}$.
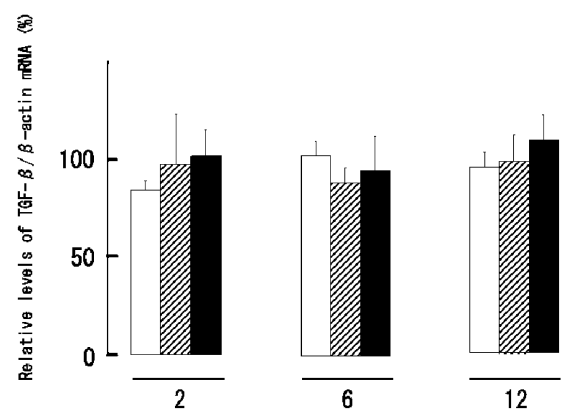

VP $0.5 \mu \mathrm{g} / \mathrm{mL}$

VP $1 \mu \mathrm{g} / \mathrm{mL}$

Time after treatment (h)

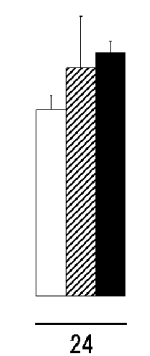

Fig. 6. TGF- $\beta$ mRNA Expression by THP-1 Cells Treated with B19 Capsid

TGF- $\beta$ mRNA expression was compared in the presence and absence of the empty capsid, and was normalized for that of $\beta$-actin using densitometry. Results are presented as the ratio (\%) of treated cells to untreated cells (mean \pm S.D., $n=3$ ).

TGF- $\beta$ mRNA, which is one of the factors that suppress TNF- $\alpha$, in the VP treated cells was not substantially changed, as compared with that in control cells, during 2 to $24 \mathrm{~h}$ after the treatment with VP antigen at 0.1 to $1 \mu \mathrm{g} / \mathrm{ml}$ (Fig. 6). There were no significant changes of the cytokine mRNA levels at other times.

Cell Surface Molecule Expression by B19 Capsid-

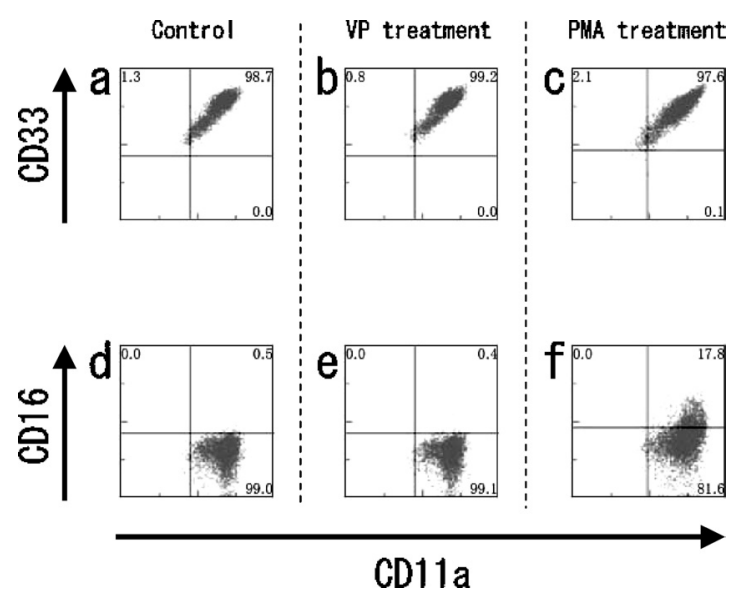

Fig. 7. Flow Cytometric Analysis of the Surface Expression of CD11a, CD16 and CD33 on THP-1 Cells

Representative dot plots of untreated THP-1 cells (a,d), cells treated with B19 capsid at $1 \mu \mathrm{g} / \mathrm{ml}(\mathrm{b}, \mathrm{e})$ and PMA at $5 \mathrm{ng} / \mathrm{ml}(\mathrm{c}, \mathrm{f})$. CD11a and CD33 (a-c), CD11a and CD16 $(d-f)$ were analyzed using CD45-gated THP-1 cells.

Treated THP-1 Cells Flow cytometric analysis of THP-1 cells with or without exposure to VP antigen $(1 \mu \mathrm{g} / \mathrm{ml})$ and PMA $(5 \mathrm{ng} / \mathrm{ml})$ showed strong surface expression of CD11a and CD33. In addition, in part of THP-1 cells with exposure to PMA showed surface expression of CD16. CD11a is a marker for macrophages and monocytes, while CD16 and CD33 is marker of macrophages and monocytes, respectively. VP treatment made no difference to the expression of these antigens compared with that by control cells (Fig. 7), it is suggested that VP antigen did not seem to promote monocyte/macrophage differentiation.

\section{DISCUSSION}

Some of the important factors involved in defense against viral infection are fever, NK cell activity, and cytotoxic T cells. Such factors are associated with the production of TNF- $\alpha$ and IL-1 by virus-infected macrophages.

TNF- $\alpha$ plays an important role in controlling viral infection by directly inducing the apoptosis or necrosis of infected cells. ${ }^{20)}$ However, TNF- $\alpha$ can also have harmful effects, so its production is strictly regulated by systems that control gene activity, mRNA stability, and translation. ${ }^{21,22)}$ In inflammatory reactions, the major source of TNF- $\alpha$ is macrophages and activated leukocytes. ${ }^{20)}$ NK cells are activated by TNF- $\alpha$, INF- $\gamma$, and IL-12, and these cells are important to the inflammatory process as well as for protection against vial infection. In the present study, we examined the change of the expression of TNF- $\alpha$ by THP-1 cells after the treatment with VP antigen. Analyses by RT-PCR demonstrated that TNF- $\alpha$ expression was transiently suppressed when THP-1 cells were treated with VP antigen. It is possible that VP participates in the regulation of TNF- $\alpha$ transcription in THP-1 cells.

IL- $1 \alpha$ and IL- $1 \beta$ are important cytokines produced by macrophages, both of which induce TNF- $\alpha$ production and fever. The ultimate function of the host defense system is elimination of the invading organism whether by phagocytosis and antibodies, or by the induction of cytotoxic $\mathrm{T}$ cells to destroy virus-infected cells. Our results showed that IL- $1 \alpha$ expression did not change significantly when THP-1 cells 
were treated with VP antigen, and that IL- $1 \beta$ expression was only slightly increased after $6 \mathrm{~h}$ of treatment. The pathophysiological significance of the transient increase of IL- $1 \beta$ level is not clear at present, and should be clarified in the future study. One possibility is that the binding of the VP antigen to its specific receptor on monocytic cells transduces signals leading to differential regulation for TNF- $\alpha$, IL- $1 \alpha$ and IL$1 \beta$ production.

Because THP-1 cells showed low expression of TNF- $\alpha$ and IL- $1 \alpha$, it seems that these monocytes did not recognize VP antigen as foreign. The monocytes become to have the major anti-virus infectious response by monocyte/macrophage differentiation. VP antigen also did not seem to promote monocyte/macrophage differentiation, because flow cytometry of THP-1 cells treated with VP antigen revealed no differences of surface molecule expression compared with control cells (Fig. 7). These results were suggested B19 infected monocytes may be not have the major anti-B19 infectious response.

The present study demonstrated that VP antigen did not promote the expression of TNF- $\alpha$ and IL- $1 \alpha$, and also monocytes/macrophage differentiation, providing an explanation for the mechanism of persistence of B19 infection. Moreover, VP antigen did not provoke fever, increased NK cell activity, or production of cytotoxic T cells. Our findings suggest that B19 may cause persistent infection of monocytes and thus spread throughout the body via the bloodstream.

\section{REFERENCES}

1) Erik D. H., Kevin E. B., Clin. Microbiol. Rev., 15, 485-505 (2002).

2) Gay N. J., Hesketh L. M., Cohen B. J., Rush M., Bates C., MorganCapner P., Miller E., Commun. Dis. Rep., 4, 104 (1994).
3) Anderson M. J., Jones S. E., Fisher-Hoch S. P., Lewis E., Hall S. M., Bartlett C. L. R., Cohen B. J., Mortimer P. P., Pereira M. S., Lancet, 321, 1378 (1983).

4) Brown K. E., Young N. S., Ann. Rev. Med., 48, 59-67 (1997).

5) White D. G., Mortimer P. P., Blake D. R., Woolf A. D., Cohen B. J., Bacon B. A., Lancet, 325, 419-421 (1985).

6) Berns K. I., "Fields' Virology, Parvoviridae the Viruses and Their Replication," ed. by Fields B. N., Knipe D. M., Howley P. M., Chanock R. M., Melnick J. L., Monath T. P., Roizman B., Straus S. E., Lippincott-Raven, Philadelphia, 1996, pp. 2173-2197.

7) Cooling L. L., Koerner T. A., Naides S. J., J. Infect. Dis., 172, 1198 1205 (1995).

8) Munakata Y., Saito-Ito T., Kumura-Ishii K., Huang J., Kodera T., Ishii T., Hirabayashi Y., Koyanagi Y., Sasaki T., Immunobiology, 106, 3449-3456 (2005).

9) Cotmore S. F., McKie V. C., Anderson L. J., Astell C. R., Tattersall P., J. Virol., 60, 548-557 (1986).

10) Ozawa K., Ayub J., Hao Y. S., Kurtzman G., Shimada T., Young N., J. Virol., 61, 2395-2406 (1987).

11) Ozawa K., Young N., J. Virol., 61, 2627-2630 (1987).

12) Shade R. O., Blundell M. C., Cotmore S. F., Tattersall P., Astell C. R., J. Virol., 58, 921-936 (1986).

13) Bansal G. P., Hatfield J. A., Dunn F. E., Kramer A. A., Brady F., Riggin C. H., Collett M. S., Yoshimoto K., Kajigaya S., Young N. S., J. Infect. Dis., 167, 1034-1044 (1993).

14) Yumoto H., Nakae H., Fujinaka K., Ebisu S., Matsuo T., Infect. Immun., 67, 384-394 (1999).

15) Arnush M., Heitmeier M. R., Scarim A. L., Marino M. H., Manning T., Corbett J. A., J. Clin. Invest., 102, 516-526 (1998).

16) Cao Y., Ohwatari N., Matsumoto T., Kosaka M., Ohtsuru A., Yamashita S., Eur. J. Physiol., 438, 239-244 (1999).

17) Chong Y. H., Sung J. H., Shin S. A., Chung J. H., Suh Y. H., J. Biol. Chem., 276, 23511-23517 (2001).

18) Joanna R. W., Mark D. B., David A. H., Dylan R. E., Aileen H., Mike J. S., Jelena G., J. Biol. Chem., 278, 51340-51346 (2003).

19) Broowitz M. J., Guenther K. L., Am. J. Clin. Pathol., 100, 534-540 (1993).

20) Brouckaert P., Fiers W., Curr. Top. Microbio. Immunol., 216, 167-187 (1996).

21) Beutler B., Am. J. Med. Sci., 303, 129-133 (1992).

22) Jongeneel C. V., Prog. Clin. Biol. Res., 388, 367-381 (1994). 